https://helda.helsinki.fi

Scriptural Reasoning as a Method of Interreligious Dialogue in China

\author{
Ruokanen, Miikka
}

2019-08

Ruokanen, M \& Li , H 2019 , ' Scriptural Reasoning as a Method of Interreligious Dialogue in China ', Interkulturelle Theologie , vol. 45 , no. 2-3 , pp. 288-302 . https://doi.org/10.1111/irom.12294

http://hdl.handle.net/10138/321174

https://doi.org/10.1111/irom.12294

publishedVersion

Downloaded from Helda, University of Helsinki institutional repository.

This is an electronic reprint of the original article.

This reprint may differ from the original in pagination and typographic detail.

Please cite the original version. 


\title{
Scriptural Reasoning as a Method of Interreligious Dialogue in China*
}

\author{
Li Huawei, Miikka Ruokanen, and David Ford
}

Li Huawei is an associate professor at the Institute of World Religions, Chinese Academy of Social Sciences, Beijing. Miileka Ruokanen is a professor of theology at the Universities of Helsinki, Nanjing, and Union Theological Seminary. David Ford is a professor of Divinity at the University of Cambridge.

\section{Abstract}

In the past two decades, scriptural reasoning (SR) has gained wide acceptance as a promising new method of interreligious dialogue among Jews, Christians, and Muslims and is rapidly gaining attention all over the world. SR as interfaith dialogue between the Abrahamic religions emerged in an Anglo-American context in the early 1990s. The first long-term experiment of SR in China was carried out in Beijing from December 2014 to September 2015 as a cooperative project between the Minzu University of China and the University of Helsinki. This SR included the sacred texts of the Chinese traditions of Taoism, Confucianism, and Buddhism alongside the canonical texts of Christianity (both Catholic and Protestant) and Islam. All the scriptural faith traditions of China were represented in this dialogue. The process of SR was carefully researched by Dr Li Huawei; the results show that it is justified to say that SR seems well-suited as a method of interfaith dialogue between the main faith traditions of China. We may assume that SR in China will have far-reacbing influence in the future.

\section{Keywords}

interreligious dialogue, scriptural reasoning, sacred and canonical texts, religions in China, Buddhism, Christianity, Confucianism, Islam, Taoism

* This text was originally published in Interkulturelle Theologie: Zeitschrift für Missionswissenschaft 2-3 (2019), $288-302$. IRM is very grateful to the editors of Interkulturelle Theologie, who gave permission for reprinting it in this issue. 
Scriptural reasoning (SR) is a new and much-discussed method of interreligious dialogue. In the past two decades, SR has gained wide acceptance among Jews, Christians, and Muslims and is rapidly gaining attention all over the world. SR as interfaith dialogue between the Abrahamic religions emerged in an Anglo-American context in the early 1990s and has been further developed mainly by the universities of Cambridge and Virginia. In recent years, Chinese scholars have also shown increasing interest in SR. It is commonly believed that SR can be extended to involve the traditional Chinese religions (i.e., Taoism, Confucianism, and Buddhism).

\section{Theoretical Ideas of SR}

SR is a practical method of interreligious dialogue that involves reading the sacred texts of other faith traditions and group reflections. SR improves the participants' awareness of their own religious identity and their understanding of religious convictions as represented by the canonical texts of other faiths. SR is based on the recognition of the plurality of wisdom traditions. While accepting the authority of the scripture of one's own faith tradition, the SR practitioner maintains an openness to the sacredness of the scriptures of other faiths.

Reciprocity exists in the recognition of oneself in relation to the other: to discover "my own identity," one must negotiate that identity through dialogue - partly overt, partly covert - with others. But mere recognition of the other does not amount to tolerance; rather, adequate knowledge of the other is the precondition to one's approval of the otherness in the other. SR fosters both willingness to live with deep differences and honest, intellectual argument for the sake of the public good.

SR moves the interfaith discussion away from doctrinal categories of analysis - which often lead to artificial abstractions of religion - to concrete, canonical texts used in religious communities. Thus, SR offers a more flexible tool for developing a richer, more complex, and more sensitive interfaith dialogue. SR is neutral in relation to the values and beliefs of religions, is based on the equal participation of all discussants, and is open in terms of its results.

SR also takes the deep and irresolvable exclusive differences between faith traditions as part of the reality of interfaith engagement. The aim, then, is to perceive differences at a higher level of clarity and thus to improve the quality of the disagreement. In this way, SR preserves differences by establishing mutual recognition of those differences. By exploiting new resources for insight into one's own and other faith traditions, one achieves a more ethical life-style. All in all, SR is a comprehensive method of dialogue, encompassing and parsing the intellectual, emotional, artistic, and moral aspects of religion. 


\section{Pioneering the Experiment in China}

The first long-term experiment of SR in China was carried out in Beijing from December 2014 to September 2015 as a cooperative project between the Minzu University of China and the University of Helsinki. Some years previously, when he was Archbishop of Canterbury, Rowan Williams had visited a number of universities and met with professors of religion in China. He then invited them to London for a symposium with academics from British universities and asked Professor David Ford of the University of Cambridge to give a paper on SR. The respondent to this paper was Professor Yang Huilin of the Renmin University of China in Beijing, and on his return to China he initiated SR there.

Most important, he and Professor You Bin of Minzu University helped to form the Institute for Comparative Scripture and Interreligious Dialogue at Minzu University, with Professor You Bin as its director and Professor Yang Huilin as the chair of its academic board. Also on the academic board were Professor Ford and Professor Peter Ochs of the University of Virginia, both of whom visited China in 2011-12 to take part in SR and consult about its development in China.

In the Minzu-Helsinki experiment, Professors You Bin and Miikka Ruokanen were the moderators. Two SR groups met simultaneously at Minzu University once a month, for a total of ten sessions, each of which lasted three hours. The participants of our SR groups were self-declared followers of a faith tradition. We included the six main faiths present in China: Taoism, Confucianism, Buddhism, Islam, Catholicism, and Protestantism. The 12 members of the first group were scholars and professionals of the six religions, two representatives from each religion, while the seven members of the second group were young students, one from each faith tradition (except Protestantism had two representatives).

The topics of each session, developed by the participants of the SR groups themselves, were the following: the purpose of the universe, the problem of poverty, the problem of suffering and evil, the role of women in religion and society, the definition of a good society, the definition of saintliness, our responsibility for the environment, and the circumstances of life after death. During the weeks before each meeting, a member of the SR groups chose a passage from the sacred texts of her/his tradition and prepared a short written commentary on that extract for group discussion. During the meeting itself, each member gave a brief oral presentation, followed by an open discussion. 


\section{Preliminary Summary of Results}

The basic results of the investigation were rather similar in the two groups: the participants of both groups considered SR to be an effective method of interfaith encounter because it challenged one to understand one's own religious tradition more deeply and, at the same time, to understand more clearly the scriptural teachings of other faith traditions. The participants affirmed that this experience clearly increased their ability not only to tolerate but also to be interested in learning from other scriptural traditions. Most of the members felt that other participants carefully listened to them and were keen to learn the views of other traditions.

Moreover, the participants felt that SR gave a clear purpose and structure for interreligious dialogue, being non-hierarchical and offering equal opportunity for each member to participate actively in discussion. SR was also found to be as equally suited for scholars as for ordinary believers, between women and men, and among young persons. The participants maintained that this SR experience motivated them to think about the concrete means of fostering moral education in their faith communities in order to strengthen civil society. Special interest was shown in cooperation through religious charities for the welfare of the people, for the equality of women and men, and for environmental protection.

Already now, it is justified to say that SR seems well-suited as a method of interfaith dialogue between the main faith traditions of China. We can expand this discussion on the canonical texts of the Abrahamic religions also to include the sacred texts of the Chinese traditions. The ten-month experiment offers a solid foundation and a very positive outlook for Chinese interfaith engagement.

As the nation's economic and political influence has continued to grow, China has enjoyed an increasing impact on regional and world affairs. In the process of its rise on the global stage, China has witnessed the growth both in number and in influence of practitioners of all religions. Since religion remains a sensitive issue in China, however, interreligious dialogue has consequently been sparse. Therefore, it is of utmost importance to develop relevant theories for and to implement interreligious dialogues.

\section{Details of the Experiment}

The following is a translated summary of the research report on the ten-month pilot of SR interreligious dialogue between the six main religions of China in Beijing, from December 2014 to September 2015. The research was carried out by Dr Li Huawei of the Institute of World Religions, Chinese Academy of Social Sciences, Beijing, China. His results were published in Chinese in the following article: "Practice of Scriptural 
Reasoning in China: Analysis of the Experiment of Interreligious Dialogue between the Six Religions of China, 2014-15," in International Journal of Sino-Western Studies [国学与西学:国际学刊] 9 (December 2015). ${ }^{1}$

\section{Procedure of the Dialogue Process}

In the first SR meeting, on 13 December 2014, Prof. You Bin proposed to the participants to expand the scope of interfaith dialogue to a broader context, i.e., from Abrahamic religions to oriental faith traditions. Prof. Miikka Ruokanen pointed out that, per his observations in China, few interreligious dialogues had touched upon points of faith and belief, limited as they were to moral and practical issues.

All participants showed keen interest in SR and identified with the principle of "respecting differences" while neither demeaning participants' religious identity nor attempting to achieve any sort of consensus. The chosen topics for discussion were to be developed by the participants themselves, as discussed above.

The participants of the meeting were all optimistic about the impact of SR in a Chinese context. Dr Zhao Jianmin, a Catholic priest from the National Seminary of Catholic Church in China, believed that SR would serve as an important way to "build identities of both other and self" and that it would help to effect meaningful dialogue between practitioners of different faith traditions. Liu Xueqiang, an imam from the Zhuxianzhen Mosque in the Henan Province, also regarded SR highly in its significance for religions in China, as he anticipated that it would offer a horizontal platform to promote better understanding of the beliefs of other religions.

You Bin introduced the purpose of the SR sessions: SR would be dedicated to the promotion of interreligious dialogues toward deeper exchanges between and mutual learning of religious traditions. It would be an experiment engaging with diverse thoughts with inner tension. Hopefully, it would develop into a "new form of academic learning" conducive to the creative transformations of faith traditions through dialogue and even to the development of understanding in one's own tradition by reading and learning from others' scriptures. In addition, such dialogue would, in its attempt to uncover universal values in Chinese narratives, aim at solving current problems by tracing them to their roots.

Such dialogue is also in itself an expression of religious thoughts. We believe that maintaining a basic religious stance should not become an obstacle to dialogue but rather provide fertile ground for new opportunities and inspirations. Although the considerable gap between assumptions and understanding may pose a great challenge and

1 This article can be found at http://www.sinowesternstudies.com/back-issuses/vol-9-2015. 
although interfaith engagement could even introduce confusion into our knowledge of one another, honesty and modesty can transform confusion and challenge into the nourishment of a richer understanding of one another.

We hope, in SR, to materialize our ideas and to be inspired by the words and deeds of others, in line with the following principles:

1. All participating members must abide by the facilitation of the moderators. For each session, a scholar representing a particular faith tradition will serve as the moderator, deciding the schedule and the order of and allotted time for each speaker.

2. Each text must be read carefully. Special attention should be paid to the rhetorical use of words, syntax, intonation, and context.

3. Discussion must first focus on the text at hand. If other sources are quoted, their relation to the text at hand should be explicated. Those who belong to the tradition of the given text may be more familiar with it, but those who are from other traditions may offer new revelations through their intuition, speculation, doubts, and even misunderstandings.

4. Discussions in and on the original languages of the texts should be expanded on for richer understanding, while, at the same time, philological details should be relevant to the discussion at hand. Nevertheless, discussions in and of original languages should not hinder creative exegeses.

5. Participants are welcome and even encouraged to offer bold new interpretations of texts and question others. Unfamiliarity, after all, is what instigates interpretation and dialogue. As it should be, showing respect for the texts of other traditions and for the traditions themselves is a necessary precondition.

6. We do not advocate suspending one's own belief but rather welcome the integration of one's own faith attitude to one's interpretation with the following caveats: (a) a personal religious stance does not enhance the authority of any given interpretation; it is rather thorough analysis of texts, inclusive of the existing, laboriously developed exegetical tradition within a religion, and prudent and moderate reasoning contribute to the depth and breadth of dialogues; and (b) interpretations should not remain fixed, since the meaning of a particular text never remains unchanged, as much for insiders as for outsiders to a faith tradition.

7. Comments from others should be listened to attentively and affably. Even criticism should not be met with downright contradiction. On the contrary, one should ask where they obtained the interpretation so as to know the reasons and assumptions behind their understanding. They should be invited to elucidate any point that is unclear. 
You Bin introduced the schedule and method of SR:

1. The responsibility of a moderator is not to decide on right and wrong, but to ensure an ordered, effective, and beneficial discussion following the above principles.

2. The first stage of SR is reading the text. Time allotted to reading each text should not exceed three minutes.

3. The second stage of SR is interpretation of the text by one who comes from that religion or tradition. This should not exceed five minutes.

4. The third stage of SR is dialogue. Participants may pose questions, seek clarification, offer their own interpretations, make comparisons, or delve deeper into the texts. A moderator should keep time, facilitate the questioning process, and offer brief summaries of the discussion at hand.

5. At the end of each session, the moderator, or a participant appointed by the moderator, should give a summary for the whole session.

6. In different traditions, the interpretation of texts cannot be divorced from their specific rituals. In such cases, ritual recitations or hymns should be utilized to allow deeper understanding of the text.

\section{The Social Influence of our Experiment: The Fourth SR Session as an Example}

A summary of the fourth session, held on 7 March 2015, was published by Chinese media in both the paper and electronic versions of China Ethnic News: Religion Weekly. This article was reprinted by China Social Sciences Press, an authoritative website in the field of humanities and social sciences. It was also reprinted by the authoritative website in Chinese academic religious studies, Chinese Academy of Social Sciences, as well as by the official websites of the six major religions in China. It attracted the attention of religious affairs departments of local governments as well. Reports on the third session had already appeared on the influential ifeng.com and were reprinted by official websites of People's Publishing House.

\section{Participants' Attitudes toward SR: Analysis of the Questionnaires}

\section{General attitude to religions other than one's own}

Based on 19 questionnaires that were filled out by the participants of the two SR groups, 14 participants showed a positive view toward and an interest in other religions, 13 thought that other religions were generally beneficial for people and society, 
16 reported liking other religions, and 16 considered other religions to be well-suited to present-day Chinese society.

\section{Evaluation on the effect of SR}

Eighteen (out of 19) participants agreed that SR would be helpful for fostering a deeper understanding of other religions, and 18 individuals felt they could better understand their own faith traditions through SR. However, more people chose "helpful, but not obvious" for the latter question than for the former. This shows that SR is more effective in helping one to understand other religions than one's own. Six out of the 19 individuals agreed that they now understood all views and beliefs of other traditions, while 13 reported that they now understood most of them. Sixteen individuals even reported believing that they learned new wisdom from others.

Seventeen participants thought they could express their real feelings about their own religion without debasing their faith identity for most of the time and even every time. Fourteen individuals felt that those from other traditions showed genuine interest in their faith, and 16 individuals even reported believing that others understood what they said. Additionally, 16 persons thought that all participants could understand each other's belief traditions.

To test their motivation in participating, we posed the question, "Do you try to listen to and understand others, or do you only promote your own faith tradition?" Eighteen participants reported "mostly" or "always" listening to others, and no one chose "I wanted to promote my own religion and expected others to accept this" and "for most of the time, I only promoted my own views." This shows participants did not intend to force their own beliefs onto others, but rather came to the SR sessions willing to listen to others.

\section{Achievement of SR}

At the inaugural session, the team organizing the SR sessions had discussed some of the principles of SR, for example, that the goal of SR is not to achieve consensus but to "disagree at a higher level of understanding" and to note logical differences behind religious terms. Thus, we asked, "Do you think reaching a consensus is the goal of SR?" to test participants' understanding. Twelve participants answered "no," while the other seven answered "yes."

The following questions reflect on the achievement of SR toward the end of boosting interfaith dialogue and toleration. When asked, "Do you think SR has a substantial significance in promoting interreligious dialogue?," all participants replied "yes"; 15 participants even chose "this is of great importance." Fourteen of them also thought that 
SR held great significance in helping individuals understand and respect other religions. On the question, "What contributes most to interfaith understanding?," ten chose SR, while four chose "university curriculum," three "life experience," and one chose "family and friends."

To understand whether the participants were concerned about dialogue with other religions weakening their own faith, we asked, "Do you think interreligious dialogue will lead to the disappearance of differences among major religions in China?" Fifteen replied, "no," while 4 chose "yes, but it needs a long time." This shows that the concept of religious multiplicity is prevalent among the participants.

The following chart summarizes participants' (the group of the professionals with 12 members) responses to the matter of SR's impact on their understanding of other religions and their own faith traditions.

\begin{tabular}{|c|c|c|c|c|c|c|c|}
\hline \multicolumn{2}{|c|}{$\begin{array}{l}\text { No. and religious } \\
\text { identity }\end{array}$} & \multicolumn{2}{|c|}{$\begin{array}{l}\text { Is SR helpful for under- } \\
\text { standing other religions / } \\
\text { traditions? If so, to what } \\
\text { extent? How? }\end{array}$} & \multicolumn{2}{|c|}{$\begin{array}{l}\text { Is SR helpful for understand- } \\
\text { ing your own religion/tradi- } \\
\text { tions? How? }\end{array}$} & \multicolumn{2}{|c|}{$\begin{array}{l}\text { Have you gained } \\
\text { new wisdom from } \\
\text { the scriptures of } \\
\text { other religions? } \\
\text { What is that } \\
\text { wisdom? }\end{array}$} \\
\hline 01 & Christian, pastor & $\begin{array}{l}\text { of great } \\
\text { help }\end{array}$ & $\begin{array}{l}\text { at least in scope } \\
\text { of thematic } \\
\text { study and } \\
\text { academic } \\
\text { methodology }\end{array}$ & $\begin{array}{l}\text { of great } \\
\text { help }\end{array}$ & $\begin{array}{l}\text { on religious her- } \\
\text { meneutics and } \\
\text { mutual under- } \\
\text { standing and its } \\
\text { application }\end{array}$ & yes & $\begin{array}{l}\text { knowledge } \\
\text { and new } \\
\text { understanding } \\
\text { in each SR } \\
\text { session }\end{array}$ \\
\hline 02 & Confucian & $\begin{array}{l}\text { helpful } \\
\text { but } \\
\text { not } \\
\text { obvi- } \\
\text { ous }\end{array}$ & $\begin{array}{l}\text { understanding of } \\
\text { other religions } \\
\text { enhanced }\end{array}$ & $\begin{array}{l}\text { helpful } \\
\text { but not } \\
\text { obvious }\end{array}$ & $\begin{array}{l}\text { understanding of } \\
\text { my own belief } \\
\text { deepened }\end{array}$ & no & \\
\hline 03 & Confucian & $\begin{array}{l}\text { helpful } \\
\text { but } \\
\text { not } \\
\text { obvi- } \\
\text { ous }\end{array}$ & not deep enough & $\begin{array}{l}\text { helpful } \\
\text { but not } \\
\text { obvious }\end{array}$ & not deep enough & no & \\
\hline 04 & Catholic, nun & $\begin{array}{c}\text { of great } \\
\text { help }\end{array}$ & & $\begin{array}{l}\text { of great } \\
\text { help }\end{array}$ & $\begin{array}{l}\text { on anthropology } \\
\text { and cosmology }\end{array}$ & no & \\
\hline 05 & Buddhist, master & $\begin{array}{l}\text { of great } \\
\text { help }\end{array}$ & & $\begin{array}{l}\text { of great } \\
\text { help }\end{array}$ & $\begin{array}{l}\text { knowledge of } \\
\text { similarities and } \\
\text { differences } \\
\text { of religions } \\
\text { deepened }\end{array}$ & yes & $\begin{array}{l}\text { different } \\
\text { understanding } \\
\text { of cosmology }\end{array}$ \\
\hline
\end{tabular}




\begin{tabular}{|c|c|c|c|c|c|c|c|}
\hline \multicolumn{2}{|c|}{$\begin{array}{l}\text { No. and religious } \\
\text { identity }\end{array}$} & \multicolumn{2}{|c|}{$\begin{array}{l}\text { Is SR helpful for under- } \\
\text { standing other religions/ } \\
\text { traditions? If so, to what } \\
\text { extent? How? }\end{array}$} & \multicolumn{2}{|c|}{$\begin{array}{l}\text { Is SR helpful for understand- } \\
\text { ing your own religion/tradi- } \\
\text { tions? How? }\end{array}$} & \multicolumn{2}{|c|}{$\begin{array}{l}\text { Have you gained } \\
\text { new wisdom from } \\
\text { the scriptures of } \\
\text { other religions? } \\
\text { What is that } \\
\text { wisdom? }\end{array}$} \\
\hline 06 & Buddhist believer & $\begin{array}{l}\text { of great } \\
\text { help }\end{array}$ & $\begin{array}{l}\text { gained some un- } \\
\text { derstanding of } \\
\text { other religions, } \\
\text { reflection on } \\
\text { my own faith } \\
\text { deepened }\end{array}$ & $\begin{array}{l}\text { of great } \\
\text { help }\end{array}$ & $\begin{array}{l}\text { understanding and } \\
\text { interpretation } \\
\text { of scripture and } \\
\text { praxis }\end{array}$ & & $\begin{array}{l}\text { tolerance and } \\
\text { listening }\end{array}$ \\
\hline 07 & $\begin{array}{l}\text { Protestant, } \\
\text { missionary }\end{array}$ & $\begin{array}{l}\text { helpful } \\
\text { but } \\
\text { not } \\
\text { obvi- } \\
\text { ous }\end{array}$ & richness in details & $\begin{array}{l}\text { helpful } \\
\text { but not } \\
\text { obvious }\end{array}$ & $\begin{array}{l}\text { especially on in- } \\
\text { spirations from } \\
\text { Buddhism and } \\
\text { Islam }\end{array}$ & yes & $\begin{array}{l}\text { more doctrinal } \\
\text { details }\end{array}$ \\
\hline 08 & Catholic & & & & & yes & $\begin{array}{l}\text { re-examining } \\
\text { some ques- } \\
\text { tions of my } \\
\text { own religion } \\
\text { from the } \\
\text { perspective } \\
\text { of other } \\
\text { religions }\end{array}$ \\
\hline 09 & $\begin{array}{l}\text { One who has yet } \\
\text { to choose what } \\
\text { to believe }\end{array}$ & $\begin{array}{l}\text { of great } \\
\text { help }\end{array}$ & $\begin{array}{l}\text { especially } \\
\text { on Islam, } \\
\text { Protestantism } \\
\text { and Catholicism }\end{array}$ & $\begin{array}{l}\text { of great } \\
\text { help }\end{array}$ & mutually beneficial & yes & $\begin{array}{r}\text { Sophia, Islamic } \\
\text { theology, and } \\
\text { hermeneutics }\end{array}$ \\
\hline 10 & Christian & $\begin{array}{l}\text { of great } \\
\text { help }\end{array}$ & & $\begin{array}{l}\text { helpful } \\
\text { but not } \\
\text { obvious }\end{array}$ & $\begin{array}{l}\text { finding weaknesses } \\
\text { in my own } \\
\text { religion }\end{array}$ & yes & $\begin{array}{l}\text { the concepts } \\
\text { of peace and } \\
\text { quietness in } \\
\text { Taoism }\end{array}$ \\
\hline 11 & Muslim & $\begin{array}{l}\text { of great } \\
\text { help }\end{array}$ & & $\begin{array}{l}\text { of great } \\
\text { help }\end{array}$ & $\begin{array}{l}\text { reflection on my } \\
\text { own beliefs } \\
\text { from the } \\
\text { perspective of } \\
\text { other cultural } \\
\text { traditions }\end{array}$ & yes & $\begin{array}{l}\text { infinite compas- } \\
\text { sion and } \\
\text { mercy of } \\
\text { Buddhism }\end{array}$ \\
\hline 12 & $\begin{array}{l}\text { One who is } \\
\text { interested } \\
\text { in Confucianism, } \\
\text { Buddhism, } \\
\text { and Christianity }\end{array}$ & $\begin{array}{l}\text { of great } \\
\text { help }\end{array}$ & & $\begin{array}{l}\text { of great } \\
\text { help }\end{array}$ & on Taoist Scripture & yes & $\begin{array}{l}\text { Islamic ritual, } \\
\text { Buddhist } \\
\text { meditation }\end{array}$ \\
\hline
\end{tabular}




\section{The Feasibility of Promoting SR in Other Communities}

When asked, "Are you willing to recommend SR to believers of other religions?" no participant chose "no"; six out of 19 chose "it depends," while the other 13 chose "yes." When asked, "Do you want SR to be practiced in your faith community?," one participant gave a resounding "no"; seven chose "it depends," while the other 11 chose "yes." This shows that the participants are slightly more willing to recommend SR to other faith communities than to their own.

\section{What Participants Learned through SR}

In addition to the insights reported in the above chart drawn from questionnaires, we asked open questions concerning what the participants learned through SR.

In the group that comprised religious experts and scholars, an imam wrote, "My knowledge structure has been expanded, and my ability to think laterally and conversely enhanced. I have learned to think from other people's perspectives, no longer being blind and subjective." A teacher and pastor from a Protestant Christian seminary said, "I have gained new religious knowledge, in particular for understanding the same topic in different scriptures." A teacher from a Taoist seminary wrote, "I have gained a deeper understanding of Taoist thinking and methodology and consequently become more confident in my own belief. I have also cultivated friendship and believe that individuals of different religions can be harmoniously integrated." A Buddhist master reported, "I have become acquainted with (1) the doctrines, religious life, and different missionary strategies of different religions, and (2) different interpretations of different view of life and values." An active follower of Confucianism commented, "My understanding of other religions has been enhanced." A scholar of religions, who is a self-declared atheist, mentioned, "SR brings knowledge and understanding."

In the group that comprised lay believers, a Buddhist believer wrote, "SR has broadened my scope of thought, improved my way of thinking, and enabled me to understand my belief tradition in a more comprehensive way." A Protestant believer reported, "My understanding has become enriched with some doctrinal details." A Catholic believer noted, "SR has given me a broader perspective." A Protestant evangelist explained: "With humility and knowledge-seeking, I have come to realize that there are different great thinking traditions." A Muslim commented, "I now see the common ground between religions and have gained a deeper understanding of religions; emotionally, I have come closer to religions other than my own, which is helpful in eliminating alienation." A participant who is still in the process of choosing a belief wrote, "I am now better acquainted with the doctrines and practice of various religions." 


\section{Some Advice for SR}

All of the participants maintain that they benefited from their participation in the SR groups. The majority of participants approved of the present programme and methods of SR, agreeing that it should be continued, with regular and irregular publications on its latest achievements. Some offered feedback on the third stage of SR, suggesting that (1) the discussion and exchange of ideas should be enhanced; and (2) intercultural dialogues be more standardized, so that it will be really "inter"-faith, or that perhaps the texts of only one religion be read each time in order that discussions might be more in-depth.

\section{Conclusion: The Significance of SR for China}

It is evident that the sessions of the two SR groups were successful and insightful explorations of SR in China. Some modifications to the methodology of SR, a programme developed in the West, were made to fit a Chinese context.

All representatives from the six major religions believed that, hand-in-hand, Chinese religions can promote Chinese moral education, individual and social morality, environmental protection, social development, and charity. Together, Chinese religions can accelerate the shaping of a good society; they may cooperate, for instance, in elevating women's social status or providing a foundation of wisdom and an organizational basis for social development and solidarity. Moreover, the moral influences of religions can contribute to the increased rule of law, social justice, and equality of all citizens.

Followers of religions universally promise that, at the turning point of modern society, they and their faith communities do their best to participate in the fostering of a good society by comforting human hearts and easing social tensions toward a better future. All the religions of China possess moral potential, an important resource for the moral renewal and rejuvenation of the nation. In sum, the religions of China can make a significant contribution to the promotion of civil society, in addition to exerting profound influence on the ethical principles in society at large.

Most of the participants deemed SR as a groundbreaking initiative for China. The participants of the two groups were well-educated, influential, and highly representative. We may assume that this first experiment of SR in China will have far-reaching influence in the future. 


\section{Recommended Reading}

Ames, Roger. Confucian Role Ethics: A Moral Vision for the 21st Century. Göttingen: Vandenhoeck and Ruprecht, 2016.

Bell, Daniel A. China's New Confucianism: Politics and Everyday Life in a Changing Society. Princeton: Princeton University Press, 2008.

Billioud, Sébastien, and Joël Thoraval. The Sage and the People: The Confucian Revival in China. Oxford University Press, 2015.

Blue Book of Religions: Annual Report on China's Religions (2008-16) (Chinese). Beijing: Social Sciences Academic Press, 2008-16.

Chen, Lai. Chinese Ancient Religion and Ethics: The Roots of Confucian Thought (Chinese). Shanghai: Sanlian Publishing Company, 2009.

Cornille, Catherine (ed.). The Wiley-Blackwell Companion to Inter-Religious Dialogue. Malden and Oxford: Wiley-Blackwell, 2013.

Cornille, Catherine, and Christopher Conway (eds). Interreligious Hermeneutics. Eugene: Cascade Books, 2010.

Deng Zimei, Chen Weihua, and Mao Qinyong. Modern Engaged Buddhism (Chinese). Lanzhou: Gansu People’s Press, 2009.

Ford, David, and C. C. Pecknold (eds). The Promise of Scriptural Reasoning. Malden and Oxford and Calton: Blackwell, 2006.

Goossaert, Vincent, and David A. Palmer. The Religious Question in Modern China. Chicago and London: University of Chicago Press, 2011.

Huang, Paulos. Confronting Confucian Understandings of the Christian Doctrine of Salvation: A Systematic Theological Analysis of the Basic Problems in the Confucian-Christian Dialogue. Leiden and Boston: Brill, 2009.

Israeli, Raphael. Islam in China: Religion, Ethnicity, Culture, and Politics. Lanham: Lexington Books, 2002.

Jin Yijiu. Contemporary Islamic Issues (Chinese). Beijing: Nationalities Press, 2008.

Johnson, Ian. The Souls of China: The Return of Religion After Mao. London: Allen Lane/ Penguin, 2017. 
Kepnes, Steven. "A Handbook for Scriptural Reasoning." In The Promise of Scriptural Reasoning. Ed. David Ford and C. C. Pecknold, 23-39 (Malden and Oxford and Calton: Blackwell, 2006.

Kuokkanen, Aleksi. Constructing Ethical Patterns in Times of Globalization: Hans Küng's Global Ethic Project and Beyond. Leiden and Boston: Brill, 2012.

Lin, Manhong. Ethical Reorientation for Christianity in China: Individual, Community and Society. Hong Kong: Chinese University of Hong Kong Press, 2010.

Mou Zhongjian. The Spirit of Chinese Culture (Chinese). Beijing: Zhonghua Press, 2016.

Moyaert, Marianne. "Scriptural Reasoning as Inter-Religious Dialogue." In The WileyBlackwell Companion to Inter-Religious Dialogue. Ed. Catherine Cornille, 64-86. Malden and Oxford: Wiley-Blackwell, 2013.

Ruokanen, Miikka, and Paulos Huang (eds). Christianity and Chinese Culture. Grand Rapids and Cambridge: Eerdmans, 2010. (Also published in Chinese by China Social Sciences Press, Beijing.)

Sacks, Jonathan. The Dignity of Difference: How to Avoid the Clash of Civilizations. London and New York: Continuum, 2002.

Scriptural Reasoning: Journal for the Study of Christian Culture (Chinese), Vol. 25. Beijing: Renmin University of China, 2011.

Simon, Karla W. Civil Society in China: The Legal Framework from Ancient Times to the "New Reform Era." Oxford: Oxford University Press, 2013.

Starr, Chloë. Chinese Theology: Text and Context. New Haven and London: Yale University Press, 2016.

Sun, Anna. Confucianism as a World Religion: Contested Histories and Contemporary Realities. Princeton and Oxford: Princeton University Press, 2013.

Tang Wenming. The Way of Confucian Religious Practice (Chinese). Beijing: Renmin University Press, 2012.

Tao, Feiya, and Yi Liu (eds). Religious Charities and Social Justice in China (Chinese). Shanghai: Shanghai University Press, 2012.

Wang, Yujie. Religions and Society in Contemporary China (Chinese). Beijing: Renmin University Press, 2006.

Welch, Sharon D. "Beyond Theology of Religions: The Epistemological and Ethical Challenges of Inter-Religious Engagement." In The Oxford Handbook of Feminist Theology, 
ed. Mary McClintock Fulkerson and Sheila Briggs, 353-70. Oxford: Oxford University Press, 2011.

Yang, Fenggang. Religion in China: Survival and Revival under Communist Rule. Oxford: Oxford University Press, 2011.

Yang Guiping. Islam in Cbina (Chinese). Beijing: Chinese Religious Press, 2007.

Zhang, Jiyu (ed.). Encyclopedia of Chinese Taoism (Chinese). Beijing: Huaxia Publishing House, 2004.

Zhang, Zigang. A Study of Contemporary Religious Conflicts and Interreligious Dialogue (Chinese). Beijing: Economic Science Press, 2009.

Zhao, Fasheng. Humanism of Original Confucianism (Chinese). Beijing: China Social Sciences Press, 2012.

Zhao, Jianmin. The Encounter between Christian Faith and Modern Chinese Culture (Chinese). Beijing: Religious Cultural Press, 2010.

Zhuo Xinping. Christianity and Cultural Context in China (Chinese). Beijing: Chinese Religious Culture Press, 2013.

Zhuo Xinping. "Academic Studies Concerning Social Politics and Religion in Contemporary China," 14 September 2017. http://www.global.ucsb.edu/lucep roject/papers/pdf/Academic Studies Concerning Social PoliticsandReligionin ContemporaryChinaZX.pdf. 